\title{
Investigating the Sorption Behavior of Cesium and Cobalt on Soil Samples
}

\author{
Ahmed F. Roushdy ${ }^{1}$, Ehab A. El-Shazly ${ }^{2}$, Bahaa A. Slah ${ }^{1}$, Reda R. Sheha ${ }^{2 a}$ and Abd-Elhakim T. Kandil ${ }^{1}$ \\ (1) Chemistry Department, Faculty of Science, Helwan University. \\ (2) Nuclear Chemistry Department, Hot Lab Center, Egyptian Atomic Energy Authority, PO.13759, Cairo, Egypt.
}

\begin{tabular}{|c|c|}
\hline ARTICLE INFO & ABSTRACT \\
\hline $\begin{array}{l}\text { Article history: } \\
\text { Received: } 25^{\text {th }} \text { Nov. } 2019 \\
\text { Accepted: } 24^{\text {th }} \text { Aug. } 2020\end{array}$ & $\begin{array}{l}\text { Two soil samples were collected from El-Dabaa site and denoted as DNS/C (Dabaa } \\
\text { natural soil / Calcite) and DNS/Q (Dabaa natural soil / Quartz). They were characterized } \\
\text { using X-Ray Fluorescence (XRF) analysis, Fourier transform infrared spectroscopy }\end{array}$ \\
\hline $\begin{array}{l}\text { Keywords: } \\
\text { Radionuclides, } \\
\text { Sorption, } \\
\text { Soil Samples }\end{array}$ & 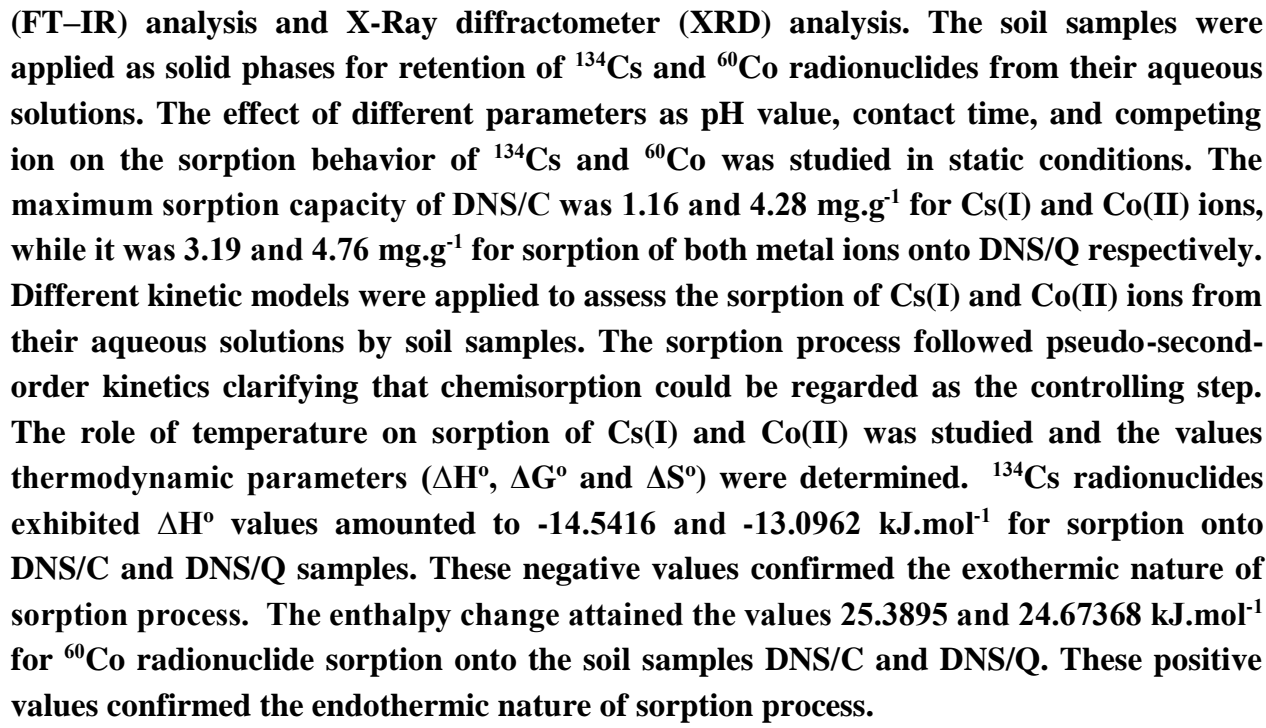 \\
\hline
\end{tabular}

\section{INTRODUCTION}

Pollution of the environment is one of the most important problems facing the world today. This problem is becoming more and more serious and needs to be resolved as quickly as possible due to its importance for the quality of the environment and the health of people. Radioactive pollution is an important problem that is attracting the attention of many scientists around the world. This is due to the growing demand for nuclear technology and the health risks accompanying with its widespread application. Nowadays, Egypt has decided to produce electricity depending on nuclear technology. Dabaa site was proposed to construction the nuclear power plant Hence, these is an extreme need to obtain information the sorption capabilities of soil samples in this area towards different radionuclides.

Radioactive waste contains a large amount of radionuclides that are dangerous for human life and environment [1, 2]. Radionuclides of cesium and cobalt are introducing into active waste streams as fission and activation products, respectively $[3,4]$. ${ }^{134} \mathrm{Cs}\left(\mathrm{T}_{1 / 2}=2.06 \mathrm{y}\right)$ that is formed as one of the common fission products of uranium-235 and other fissionable isotopes in nuclear power reactors. It constituents a large problem because cesium has a high water solubility and easily spreads in surroundings environment. Cesium mobility can be considerably reduced by sorption of its ions on soil and surrounding 
minerals [5]. ${ }^{60} \mathrm{Co}$ is a short-lived radioactive isotope produced in nuclear reactors. It can't be produced by nuclear fission. It was produced in small amounts as a result of interaction of neutron with structural materials of the reactor as well as during the routine operation of nuclear power plants. Small quantities can be also released as contaminants in the cooling water or as radioactive waste. It is a corrosive and toxic element widely observed in nuclear effluents and seriously affects the environment [6].

For radiological safety, it important to remove the radioactive constituents from waste streams and preserve them a stable from. There are many methods have been successfully applied in removing different radionuclides from hazardous wastes. These methods include flotation [7], common precipitation [8], liquid-liquid extraction [9], membrane processes [10], electrocoagulation [11], adsorption [12] and solid phase extraction technology $[13,14]$. The aim of this work is to explore the sorption capabilities of some soil samples collected from north coast of Egypt at El-Dabaa site towards $\mathrm{Cs}(\mathrm{I})$ and $\mathrm{Co}(\mathrm{II})$ ions under different experimental conditions.

\section{EXPERIMENTAL}

\subsection{Site of the study}

Nine soil samples and three seawater samples were collected from El-Dabaa site in Egypt that locate on the Mediterranean Sea coast of the North Western desert lies between longitudes $\left(28^{\circ} 22^{\prime}-28^{\circ} 31^{\prime}\right) \mathrm{E}$ and latitudes $\left(31^{\circ} 02^{\prime}-31^{\circ} 05^{\prime}\right) \mathrm{N}$ that is about $400 \mathrm{~km}$ from capital
(Cairo) and $150 \mathrm{~km}$ west of Alexandria. Long of the site is $15 \mathrm{~km}$ and its wide is $4 \mathrm{~km}$ given in figure (1). Only, two soil samples were selected and included tin this study.

\subsection{Chemicals and reagents}

All chemicals and reagents used in this work were evaluated analytically and used without further purifications. Hydrochloric acid ( $\mathrm{HCl})$, sodium hydroxide $(\mathrm{NaOH})$, sodium chloride $(\mathrm{NaCl})$, calcium chloride $\left(\mathrm{CaCl}_{2} .6 \mathrm{H}_{2} \mathrm{O}\right)$, magnesium nitrate $\left(\mathrm{Mg}\left(\mathrm{NO}_{3}\right)_{2} \cdot 6 \mathrm{H}_{2} \mathrm{O}\right)$, manganese chloride $\left(\mathrm{MnCl}_{2} \cdot 4 \mathrm{H}_{2} \mathrm{O}\right)$ and aluminum chloride $\left(\mathrm{AlCl}_{3} \cdot 6 \mathrm{H}_{2} \mathrm{O}\right)$ were purchased from Sigma-Aldrich (USA).

\subsection{Preparation of radiotracers}

${ }^{134} \mathrm{Cs}$ and ${ }^{60} \mathrm{Co}$ radioisotopes were prepared by neutron irradiation of $0.01 \mathrm{~g}$ of cesium chloride and cobalt chloride. The irradiation process was conducted in the Egyptian research reactor in Anshas. Each target was wrapped in a thin plate, placed in a radiation tray, and exposed to a neutron flux of $10^{14} \mathrm{n} \cdot \mathrm{Cm}^{-2} \cdot \mathrm{s}^{-1}$. The irradiated targets were allowed to cool for a period. After cooling, the irradiated samples were dissolved in double distilled water. A stock solution of $1000 \mathrm{mg} \mathrm{L}^{-1} \mathrm{Cs}(\mathrm{I})$ and $\mathrm{Co}(\mathrm{II})$ ions were prepared separately by dissolving the essential amounts of Cesium chloride $(\mathrm{CsCl})$ and cobalt chloride $\left(\mathrm{CoCl}_{2} \cdot 6 \mathrm{H}_{2} \mathrm{O}\right)$ in a certain volume of double distilled water, whereby it has become possible to prepare the desired concentrations of the adsorbate solution by suitable dilution.

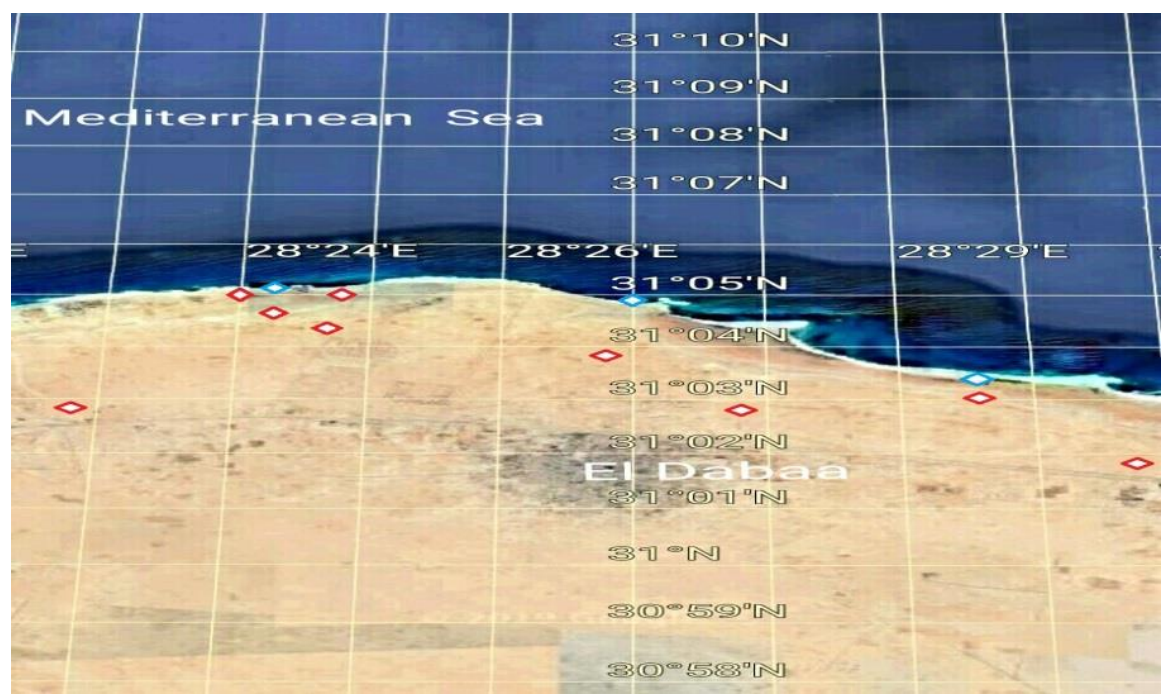

Fig. (1): Location of study area, El Dabaa, Northwestern Coast, Egypt 


\subsection{Characterization}

The physical and chemical properties of the soil samples, in the present study, were characterized using $\mathrm{X}$-Ray Fluorescence (XRF) analysis using on a PANalytical PW2404 X-ray fluorescence spectrometer for determining the chemical composition. The functional groups of soil samples were determined using FT-IR spectrophotometer of type Nicolet 10 from Thermo (USA). The phase structure was investigated using X-Ray diffractometer. The analysis was achieved using PAN alytical X'Pert PRO through monochromator, Cu-radiation $(\lambda=1.5418 \AA)$ run at a voltage $45 \mathrm{kV}$, current $35 \mathrm{~mA}$ and scanning speed $0.03^{\circ} \cdot \mathrm{sec}^{-1}$

\subsection{Batch experiments}

Sorption studies of $\mathrm{Cs}(\mathrm{I})$ and $\mathrm{Co}(\mathrm{II})$ ions onto soil samples were performed by stirring a definite weight of soil samples with $10 \mathrm{~mL}$ of $100 \mathrm{mg} . \mathrm{L}^{-1}$ metal ion solution of $\mathrm{Cs}(\mathrm{I})$ and $\mathrm{Co}$ (II) ions, in closed glass bottles. The solutions were traced with the corresponding radioactive isotopes ${ }^{134} \mathrm{Cs}$ and ${ }^{60} \mathrm{Co}$ and their initial $\mathrm{pH}$ were adjusted at 6 and 5.8 values by addition of $0.1 \mathrm{M} \mathrm{HCl}$ or $0.1 \mathrm{M} \mathrm{NaOH}$ solutions. At certain time intervals, the supernatants were separated by centrifugation and subjected to radiometric analysis to determine the activity of the studied radionuclides. The radioactivity of studied isotopes was $\gamma$-assayed using a multi-channel counter connected to a $\mathrm{NaI}$ scintillation detector. The uptake percentage $(\mathrm{U} \%)$ was calculated using the following equation:

$$
\mathrm{U} \%=\frac{\mathrm{A}_{\mathrm{i}}-\mathrm{A}_{\mathrm{f}}}{\mathrm{A}_{\mathrm{i}}} \times 100
$$

where: $A_{i}$ and $A_{f}$ are initial and final radioactivities of studied radionuclides. The maximum sorption capacity $\left(\mathrm{Q}_{\max }, \mathrm{mg} \cdot \mathrm{g}^{-1}\right)$ for the two soil samples was determined by repeated equilibration of certain weights of soil samples with a definite volume of $100 \mathrm{mg} . \mathrm{L}^{-1} \mathrm{Cs}(\mathrm{I})$ and $\mathrm{Co}(\mathrm{II})$ solutions spiked with the corresponding radioactive isotopes at certain initial $\mathrm{pH}$ values. The samples were stirred at room temperature for $24 \mathrm{~h}$. Then, the supernatants were drag, centrifuged and $\gamma$-radioassayed. An equal volume of the original solution of studied ions was added to the soil samples and stirred until achieving equilibrium. The former procedure were repeated till no additional sorption occurred for both $\mathrm{Cs}(\mathrm{I})$ and $\mathrm{Co}(\mathrm{II})$. The sorbed amount $\left(\mathrm{q}_{\mathrm{e}}\right)$ onto soil sample for each equilibration process from the equation[15]:

$$
\mathrm{q}_{\mathrm{e}}=\left(\mathrm{C}_{\mathrm{o}}-\mathrm{C}_{\mathrm{e}}\right) \times \frac{\mathrm{V}}{\mathrm{m}}
$$

where: $C_{o}$ and $C_{f}$ is the initial and final concentrations (mg. $\mathrm{L}^{-1}$ ) of $\mathrm{Cs}(\mathrm{I})$ and $\mathrm{Co}(\mathrm{II})$ metal ions, $\mathrm{V}$ is the volume of solution ( $\mathrm{L}$ ) and $\mathrm{m}$ is the weight of soil sample $(\mathrm{g})$. The effect of $\mathrm{pH}$ value was studied at ranges from 1 to 11 for $\mathrm{Cs}(\mathrm{I})$ and $\mathrm{Co}(\mathrm{II})$ solutions. After equilibration, the supernatants radioactivity was radiometrically. An additional set of experiments were performed as previously described to clarify the effect of certain parameters.

\section{RESULTS AND DISCUSSION}

The specific surface area had been determined according to Brunauer-Emmett-Teller (BET). The soil samples have surface area of 10.532 and $17.970 \mathrm{~m}^{2} \cdot \mathrm{g}^{-1}$ for DNS/C and DNS/Q respectively.

\subsection{Characterization}

The chemical composition of DNS/C and DNS/Q soil samples were determined using quantitative XRF analysis and results are presented in Table (1). XRF analysis shows that calcium oxide $(\mathrm{CaO})$ was the most abundant component $(43.83 \%)$ in $\mathrm{DNS} / \mathrm{C}$ sample while silica $\left(\mathrm{SiO}_{2}\right)$ was the most abundant component (39.65\%) in DNS/Q sample. The oxides silica $\left(\mathrm{SiO}_{2}\right)$, sodium oxide $\left(\mathrm{Na}_{2} \mathrm{O}\right)$ and magnesium oxide $(\mathrm{MgO})$ were detected in low percentages amounted to 5.3, 2.53 and $2.1 \%$ in DNS/C sample. In addition, other oxides like titanium oxide $\left(\mathrm{TiO}_{2}\right)$, alumina $\left(\mathrm{Al}_{2} \mathrm{O}_{3}\right)$, iron oxide $\left(\mathrm{Fe}_{2} \mathrm{O}_{3}\right)$, manganese oxide $(\mathrm{MnO})$, potassium oxide $\left(\mathrm{K}_{2} \mathrm{O}\right)$, phosphorus pentoxide $\left(\mathrm{P}_{2} \mathrm{O}_{5}\right)$ and sulfur trioxide $\left(\mathrm{SO}_{3}\right)$ were detected at levels less than $2 \%$ of the total weight of DNS/C soil sample. On other hand, DNS/Q sample mainly composed from calcium oxide $(\mathrm{CaO})$, alumina $\left(\mathrm{Al}_{2} \mathrm{O}_{3}\right)$, magnesium oxide $(\mathrm{MgO})$ and iron oxide $\left(\mathrm{Fe}_{2} \mathrm{O}_{3}\right)$ with percentages amounted to $22.36,8.26$, 3.50 and $2.53 \%$, respectively. Other oxides like potassium oxide $\left(\mathrm{K}_{2} \mathrm{O}\right)$, titanium oxide $\left(\mathrm{TiO}_{2}\right)$, manganese oxide $(\mathrm{MnO})$, sodium oxide $\left(\mathrm{Na}_{2} \mathrm{O}\right)$, phosphorus pentoxide $\left(\mathrm{P}_{2} \mathrm{O}_{5}\right)$ and sulfur trioxide $\left(\mathrm{SO}_{3}\right)$ were detected at levels less than $2 \%$ of the total composition.

The loss in the ignition of DNS/C and DNS/Q soil samples was found to be 35.06 and $18.16 \%$. The high loss due to ignition could be mainly attributed to calcium carbonate decomposition that lead to formation of $\mathrm{CaO}$ and carbon dioxide $\left(\mathrm{CO}_{2}\right)$ [16]. 
Table (1): Chemical composition of DNS/C and DNS/Q soil samples.

\begin{tabular}{|c|c|c|}
\hline \multirow{2}{*}{ Compound } & \multicolumn{2}{|c|}{ Percentage $(\% \mathrm{w} / \mathrm{w})$} \\
\hline & $\mathrm{DNS} / \mathrm{C}$ & DNS/Q \\
\hline Silica $\left(\mathrm{SiO}_{2}\right)$ & 5.3 & 39.65 \\
\hline Titanium oxide $\left(\mathrm{TiO}_{2}\right)$ & 0.12 & 0.46 \\
\hline Alumina $\left(\mathrm{Al}_{2} \mathrm{O}_{3}\right)$ & 0.88 & 8.26 \\
\hline Iron oxide $\left(\mathrm{Fe}_{2} \mathrm{O}_{3}\right)$ & 1.08 & 2.53 \\
\hline $\begin{array}{l}\text { Manganese oxide } \\
(\mathrm{MnO})\end{array}$ & 0.04 & 0.05 \\
\hline $\begin{array}{l}\text { Magnesium oxide } \\
(\mathrm{MgO})\end{array}$ & 2.1 & 3.50 \\
\hline Calcium oxide $(\mathrm{CaO})$ & 43.83 & 22.36 \\
\hline Sodium oxide $\left(\mathrm{Na}_{2} \mathrm{O}\right)$ & 2.53 & 0.50 \\
\hline Potassium oxide $\left(\mathrm{K}_{2} \mathrm{O}\right)$ & 0.32 & 1.98 \\
\hline $\begin{array}{l}\text { Phosphorus pentoxide } \\
\left(\mathrm{P}_{2} \mathrm{O}_{5}\right)\end{array}$ & $<0.01$ & $<0.01$ \\
\hline Chlorine $(\mathrm{Cl})$ & 7.89 & 2.06 \\
\hline Sulfur trioxide $\left(\mathrm{SO}_{3}\right)$ & 0.15 & 0.09 \\
\hline L.O.I & 35.06 & 18.16 \\
\hline
\end{tabular}

The FT-IR spectrum of DNS/C and DNS/Q are shown in figure (2). The bands detected at $\sim 1485$ $\sim 1080, \sim 1788, \sim 855$, and $\sim 711 \mathrm{~cm}^{-1}$ could be referred to absorption vibration of $\mathrm{CO}_{3}{ }^{2-}$ groups in both soil samples. They were reported as common features of carbonate ions in calcium carbonate and could be considered as the basic patterns of vibration for this molecule $[17,18]$.

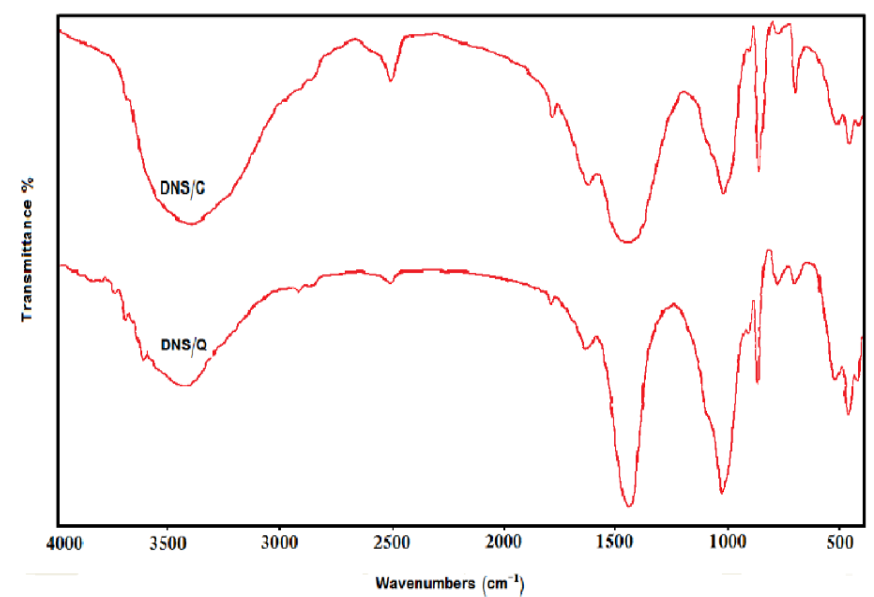

Fig. (2): FT-IR spectra of: a) DNS/C and b) DNS/Q soil samples
The frequency at $1788 \mathrm{~cm}^{-1}$ could be ascribed to $\mathrm{C}=\mathrm{O}$ stretching vibration. The frequency at $2522 \mathrm{~cm}^{-1}$ was identified for calcite in the samples $[19,20]$. The absorption bands at $2920-2854 \mathrm{~cm}^{-1}$ was attributed to $\mathrm{C}-\mathrm{H}$ vibration [21]. The band at $2626 \mathrm{~cm}^{-1}$ is a shoulder band accompanying with absorption of carbonate while that observed at $2522 \mathrm{~cm}^{-1}$ was due to calcite/dolomite discrimination [22].The broad range of $3600-3100 \mathrm{~cm}^{-1}$ was dedicated to $\mathrm{O}-\mathrm{H}$ bonding stretching vibrational of water of hydration. The band exhibited at $1670-1600 \mathrm{~cm}^{-1}$ could be referred to $\mathrm{O}-\mathrm{H}$ bending vibrational modes for DNS/Q soil sample. The frequency at 455 and $540 \mathrm{~cm}^{-1}$ could be attributed to metal oxygen stretching vibrational modes [23].The band observed at $3686 \mathrm{~cm}^{-1}$ was corresponded to $\mathrm{Mg}-\mathrm{OH}$ stretching vibration while the frequency at $984.6 \mathrm{~cm}^{-1}$ was indicative to the stretching vibration of Si-O. The band presented at $794 \mathrm{~cm}^{-1}$ could be avouched to $\mathrm{Si}-\mathrm{O}-\mathrm{Si}$ symmetric stretching vibrations while the band at $470 \mathrm{~cm}^{-1}$ was ascribed to O-Si-O bending vibrations [24].

The crystalline structure for both soil samples was analyzed using $\mathrm{X}$-ray diffraction pattern and data obtained are given in figure (3). DNS/C exhibited characteristics peaks of calcite, magnesium at $2 \theta$ values of $23.29^{\circ}, 29.62^{\circ}, 36.24^{\circ}, 39.66^{\circ}, 43.39^{\circ}$ and $47.76^{\circ}$, which correlated with $(h k l)$ indices of (012), (104), (110), and (113), (202), and (024), respectively. The data illustrate that the crystal structure of the soil was trigonal (hexagonal axes) [25]. The strongest peak for DNS/C sample was observed at $2 \theta$ value of $29.62^{\circ}$ with intensity $100 \%$ and $d$-spacing 3.02 . However, peaks were also observed at $21.04^{\circ}, 26.80^{\circ}$, $46.00^{\circ}, 50.33^{\circ} 26.39^{\circ}, 27.41^{\circ}$, and $33.28^{\circ}$ that could be ascribed to the minerals quartz, graphite, halite, and hematite, respectively [26-29]. X-ray diffraction pattern of DNS/Q exhibited characteristics peaks of quartz at $2 \theta$ values of $21.14^{\circ}, 26.89^{\circ}, 36.83^{\circ}$, $39.79^{\circ}, 40.59^{\circ}, 42.72^{\circ}, 46.08^{\circ}, 50.41^{\circ}$ and $55.24^{\circ}$ that correlated with $(h k l)$ indices of (100), (101), (110), and (102), (111), (200), (201), (112) and (103) respectively. The data illustrate that DNS/Q soil sample had trigonal crystal structure (hexagonal axes)[30]. 

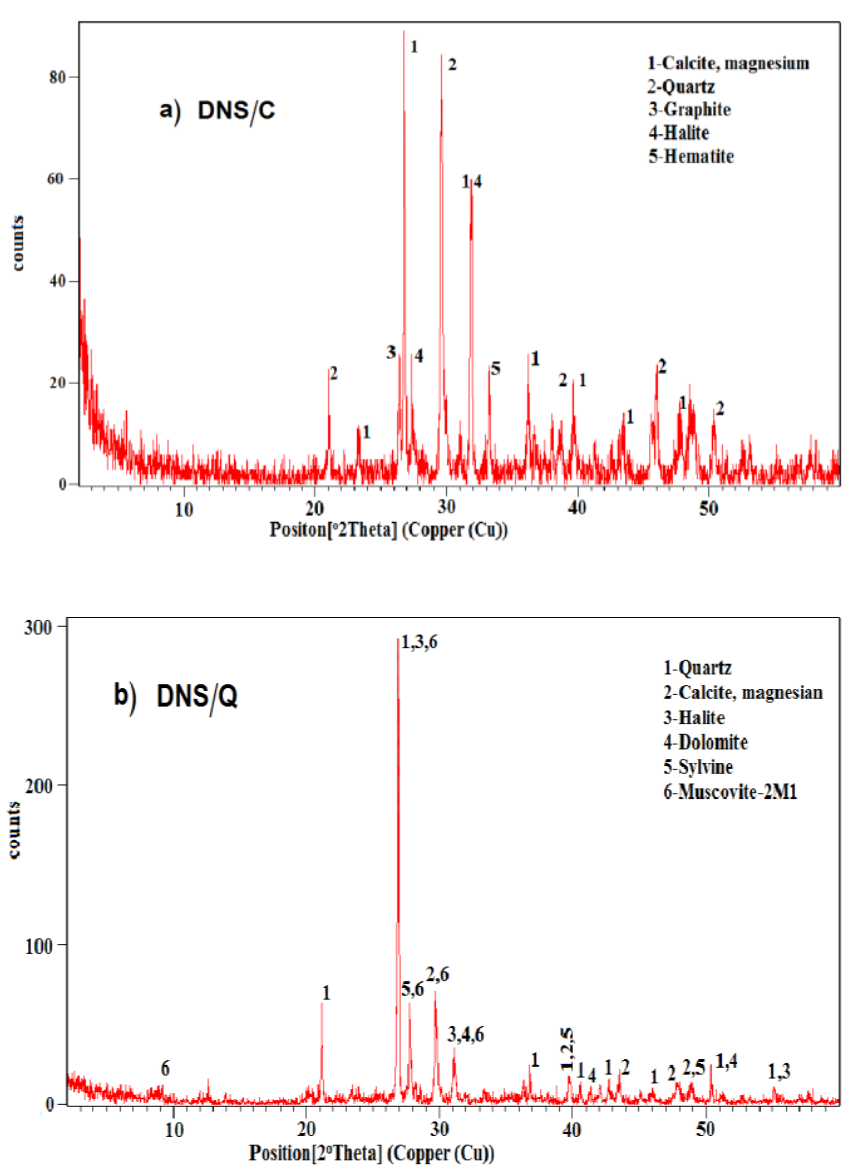

Fig. (3): XRD patterns of soil samples: a) DNS/C and b) DNS/Q

The strongest peak for DNS/Q was observed at $2 \theta$ value of $26.89^{\circ}$ with intensity $100 \%$ and $d$-spacing 3.32 . There are peaks also observed at $29.73^{\circ}, 43.52^{\circ}, 47.90^{\circ}$, $48.87^{\circ}$ and $31.07^{\circ}$ and $41.34^{\circ}, 27.72$ and $8.75^{\circ}$ corresponding to calcite-magnesium, halite, dolomite, sylvine and muscovite-2M1 minerals respectively [25, 28, 31-33].

The crystallite size (t) of the soil samples was determined by using data of XRD by using DebyeScherrer equation:

$$
\mathrm{t}=\frac{\mathrm{K} \cdot \lambda}{\beta \cdot \operatorname{Cos} \theta}
$$

where: $\mathrm{t}$ is the crystallite soil sample size in $(\mathrm{nm}), \mathrm{k}$ is a constant reliant on crystallite shape and has the value of $0.89, \lambda$ is the wavelength of $\mathrm{X}$-rays and has the value of $0.1542 \mathrm{~nm}, \theta$ is the angle of diffraction gives in (degree) and $\beta$ is the peak width of full diffraction at half maximum intensity (FWHM). The mean crystallite sizes, estimated using Scherrer equation, were 41.34 and $100.17 \mathrm{~nm}$ for DNS/C and DNS/Q respectively. The values demonstrate the nanosized structures of the applied soil samples.

\subsection{Sorption study}

\subsubsection{Effect of time}

The change in uptake percent of $\mathrm{Cs}(\mathrm{I})$ and $\mathrm{Co}(\mathrm{II})$ with time was observed at different periods ranged from $5 \mathrm{~min}$ to $48 \mathrm{~h}$. The sorption was performed using batch technique and obtained data are shown in figure (4). The data illustrate that the uptake of $\mathrm{Cs}(\mathrm{I})$ and $\mathrm{Co}$ (II) by DNS/C and DNS/Q soil samples had two different steps. The first step included a sharp increase in the uptake rate with contact time up to $4 \mathrm{~h}$ and the final step referred to a slow uptake rate until reaching equilibrium after $24 \mathrm{~h}$. The uptake percentages of $\mathrm{Cs}(\mathrm{I})$ were 22.59 and $47.14 \%$ for sorption onto DNS/C and DNS/Q soil samples while the values 79.20 and $90.15 \%$ were recorded for sorption of Co(II) onto DNS/C and DNS/Q samples, respectively. The rapid sorption of $\mathrm{Cs}(\mathrm{I})$ and $\mathrm{Co}(\mathrm{II})$ by soil samples can be illustrates that the increasing of active sites at initial step available for sorption of studied ions related to the concentration of $\mathrm{Cs}(\mathrm{I})$ and $\mathrm{Co}(\mathrm{II})$ ions interpreting the increasing of sorption rate.
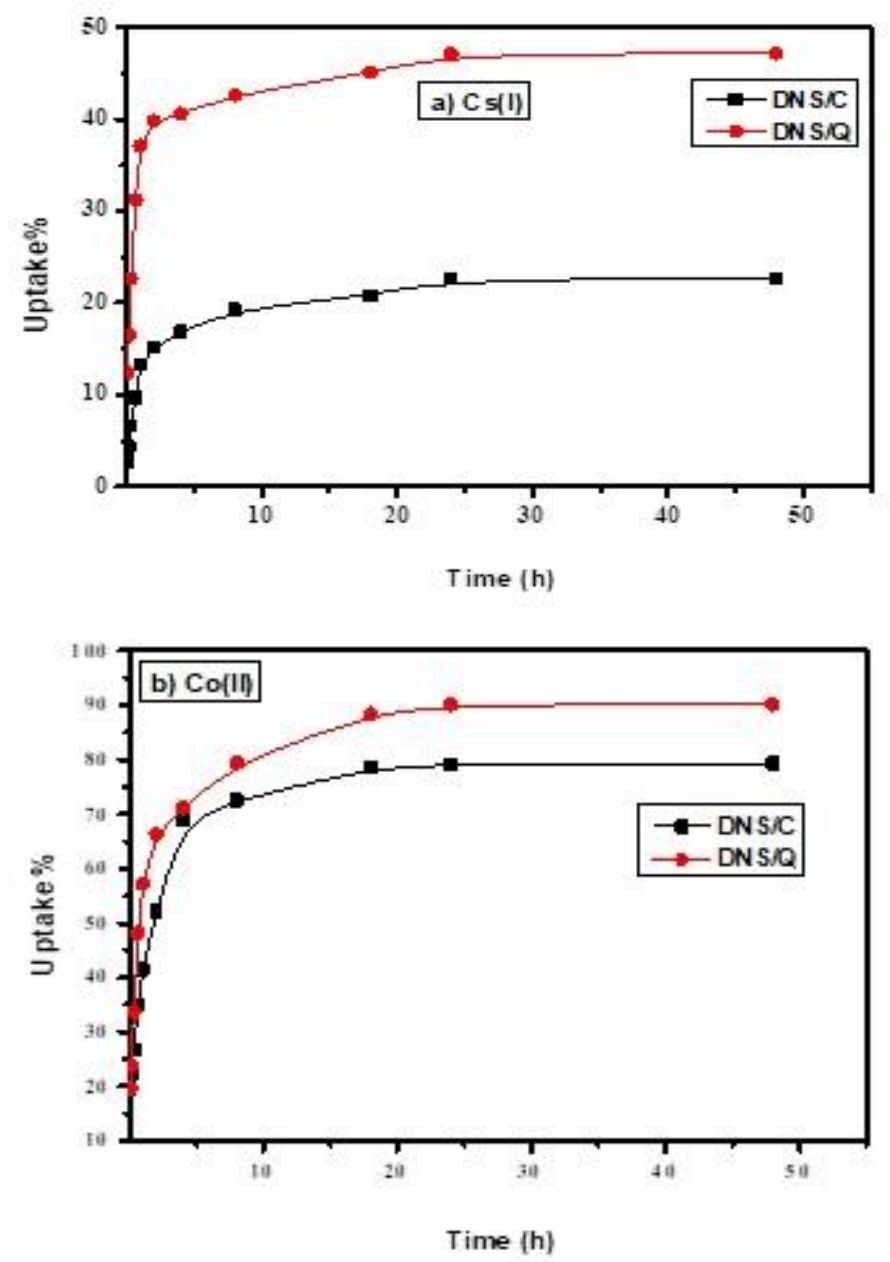

Fig. (4): Effect of contact time on uptake of: a) cesium and b) cobalt ions onto the studied soil samples $\left(\mathrm{pH}_{\mathrm{i}(\mathrm{Cs})}=6-\mathrm{pH}_{\mathrm{i}(\mathrm{Co})}=5.8, \mathrm{~V} / \mathrm{m}\right.$ $=100 \mathrm{~mL} \cdot \mathrm{g}^{-1}, \mathrm{C}_{0}=20 \mathrm{mg} \cdot \mathrm{L}^{-1}$, temp. $=25^{\circ} \mathrm{C}$ ).

Arab J. Nucl. Sci. Appl., Vol. 53, 4, (2020) 
By increasing sorption, active sites on soil surface started to decrease and ions started to compete between themselves for active sites. Subsequently, the uptake percent went down [34]. The maximum sorption amounts $\left(Q_{\max }\right)$ were determined and found to be 1.16 and $2.39 \mathrm{mg} \cdot \mathrm{g}^{-1}$ for sorption of $\mathrm{Cs}(\mathrm{I})$ onto $\mathrm{DNS} / \mathrm{C}$ and DNS/Q while $Q_{\max }$ for sorption of Co(II) onto DNS/C and DNS/Q were 4.28 and $4.76 \mathrm{mg}^{-g^{-1}}$, respectively.

\subsubsection{Effect of $\mathrm{pH}$}

Solution $\mathrm{pH}$ is an important dominant parameter in sorption processes because of its effect on the surface properties of soil samples and the ionic form of the metal ion in aqueous solution [35]. The effect of $\mathrm{pH}$ value on uptake percentages of soil samples for $\mathrm{Cs}(\mathrm{I})$ and $\mathrm{Co}$ (II) ions is illustrated in figure (5). The uptake percentages of cesium ion were increased by rising $\mathrm{pH}$ value from 2 to 7. This is due to $\mathrm{H}_{3} \mathrm{O}^{+}$had large concentration at lower $\mathrm{pH}$ values and competed with cesium ions for active sites [36, 37]. With increasing $\mathrm{pH}$, the concentration of $\mathrm{H}_{3} \mathrm{O}^{+}$decreased and the deprotonation of active site on soil surface increased that enable these sites to attract cesium ions and hence the uptake of cesium increased. At higher $\mathrm{pH}$ values, the uptake of $\mathrm{Cs}(\mathrm{I})$ was slightly decreased with increasing $\mathrm{pH}$ value up to 11. Similar behavior was reported by other investigators [38]. The maximum sorption of cesium was detected at $\mathrm{pH} 6$.
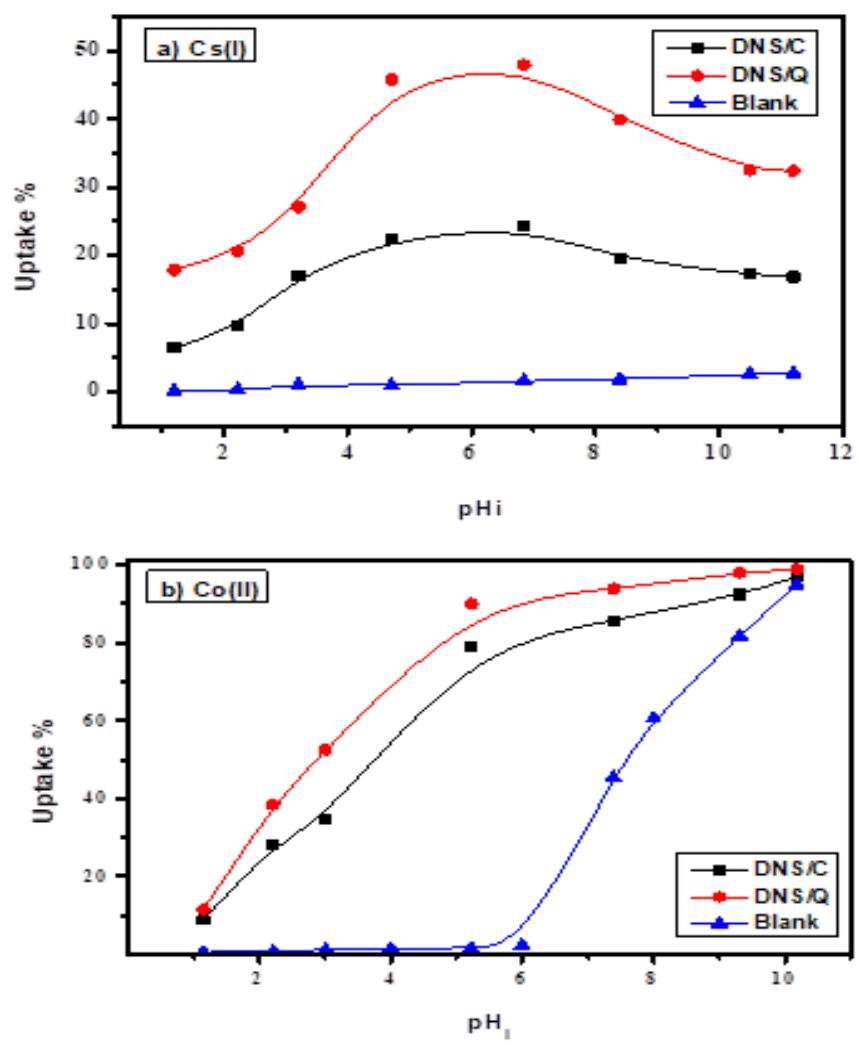

Fig. (5): Effect of pH value on uptake of $\mathrm{Cs}(\mathrm{I})$ and $\mathrm{Co}(\mathrm{II})$ ions onto the studied soil samples $\left(t_{\text {eq }}=24 \mathrm{~h} ; \mathrm{V} / \mathrm{m}\right.$ $=100 \mathrm{~mL} . \mathrm{g}^{-1} ; \mathrm{C}_{0}=20 \mathrm{mg} . \mathrm{L}^{-1}$; temp. $=25^{\circ} \mathrm{C}$ ).
The uptake of $\mathrm{Co}$ (II) on the applied soil samples is presented in figure (5). The plots clarify that the uptake of $\mathrm{Co}$ (II) increased with rising $\mathrm{pH}$ value from 1 up to 6 . At higher $\mathrm{pH}$ value, $\mathrm{Co}$ (II) uptake slightly increased till reaching equilibrium, where the uptake percentage attained a constant value with rising $\mathrm{pH}$ value up to 11 . To verify the solubility extent of both metal ions under the applied experimental conditions, a blank solution of metal ions had been studied without presence of soil samples to achieve the solubility range of these metal ions. The results show that $\mathrm{Cs}(\mathrm{I})$ ions are completely soluble over the studied $\mathrm{pH}$ range that extended from 1-11, where $\mathrm{Cs}^{+}$is the predominant species over this $\mathrm{pH}$ range. On the other hand, $\mathrm{Co}$ (II) ions exhibited a different solubilities over different $\mathrm{pH}$ values, $\mathrm{Co}$ (II) precipitation started at $\mathrm{pH} \sim 6.5$ at which the removal was attributed to the precipitation of $\mathrm{Co}$ (II) ions. At these conditions, $\mathrm{Co}(\mathrm{OH})_{2}$ were the predominant species [39]. The uptake percent (U\%) of $\mathrm{Cs}(\mathrm{I})$ ions onto DNS/C and DNS/Q samples attained the values 23.2 and $47.8 \%$ at initial $\mathrm{pH} 6$ while $\mathrm{Co}$ (II) ions attained the values 78.9 and $90.1 \%$ at initial $\mathrm{pH} 5.8$, respectively. Based on these data, $\mathrm{pH} 6$ and 5.8 was applied in the rest of experiments for studying the sorption of $\mathrm{Cs}(\mathrm{I})$ and $\mathrm{Co}(\mathrm{II})$ ions on the applied soil samples.

\subsubsection{Effect of competing ion}

The influence of presence of varied initial concentrations of different cations as $\mathrm{Na}^{+}$(univalent), $\mathrm{Ca}^{2+}, \mathrm{Mg}^{2+}$ and $\mathrm{Mn}^{2+}$ ( bivalent) and $\mathrm{Al}^{3+}$ (trivalent) on uptake of $\mathrm{Cs}(\mathrm{I})$ and $\mathrm{Co}$ (II) onto the used soil samples is clarified in figure (6). The data illustrate that the uptake of $\mathrm{Cs}(\mathrm{I})$ decreased with presence of increased concentration of the metal ions $\mathrm{Na}^{+}, \mathrm{Ca}^{2+}, \mathrm{Mg}^{2+}, \mathrm{Mn}^{2+}$ and $\mathrm{Al}^{3+}$. The decrease in $\mathrm{Cs}(\mathrm{I})$ uptake increased with increasing the initial concentration of these competing ions up to $0.4 \mathrm{M}$, figure (6a). The closer inspection to these plots clarifies a sharp decrease in $\mathrm{Cs}(\mathrm{I})$ uptake with rising the initial concentration of all competing cations up to $0.1 \mathrm{M}$. At higher concentration, the uptake percent of $\mathrm{Cs}(\mathrm{I})$ slightly decreased with increasing the initial concentration of all competing ions up to $0.4 \mathrm{M}$. The deterious effect of the applied competing cations attained the order: $\mathrm{Al}^{+3}>\mathrm{Mg}^{+2}>\mathrm{Mn}^{+2}>\mathrm{Ca}^{+2}>\mathrm{Na}^{+}$. Additionally, the role of the previously mentioned interfering cations on uptake of $\mathrm{Co}$ (II) ions is illustrated in figure (6b). The plots exhibit a decrease in the uptake 
of $\mathrm{Co}$ (II) with presence of such cations and this depress in uptake percent of $\mathrm{Co}(\mathrm{II})$ is directly proportional with the initial concentration of the applied competing cations.

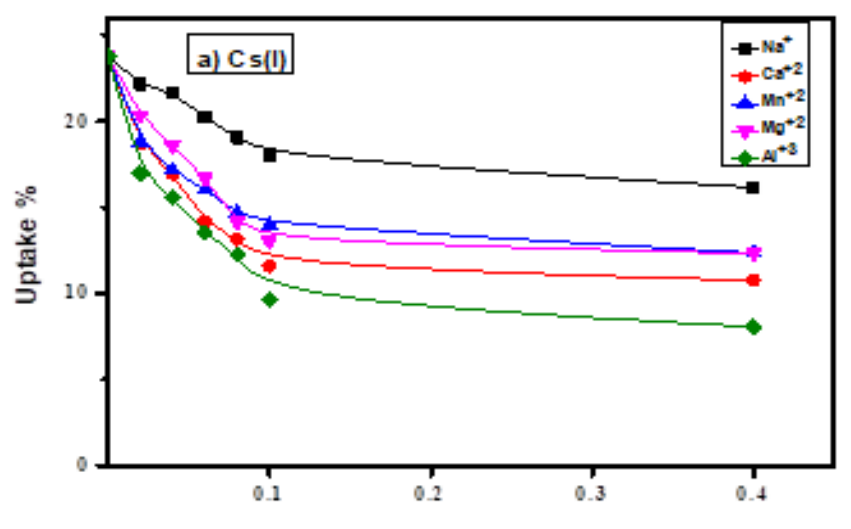

Competing ions concentration (M)

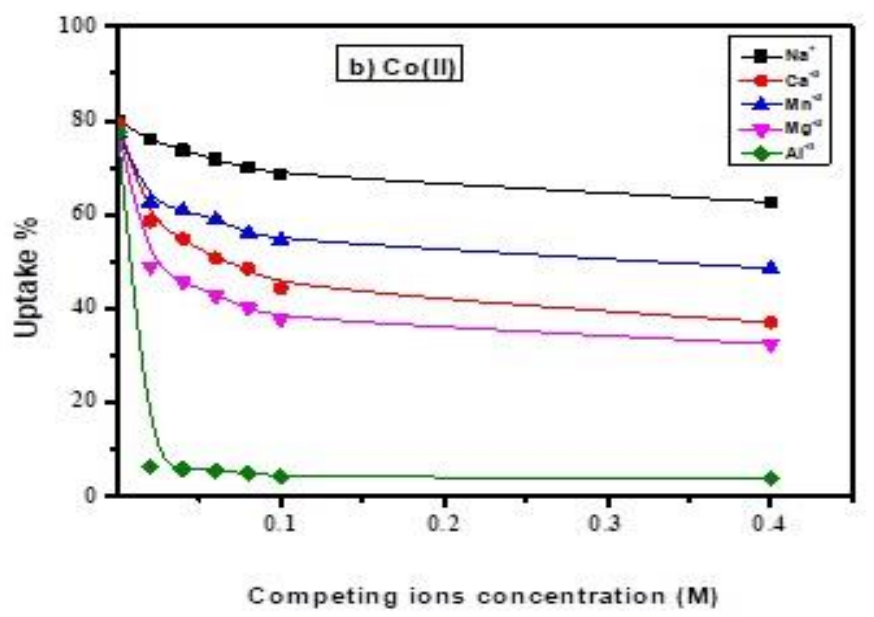

Fig. (6): Effect of competing ions on uptake of: a) $\mathrm{Cs}(\mathrm{I})$ and b) $\mathrm{Co}$ (II) ions onto DNS/C soil sample $\left(\mathrm{pH}_{\mathrm{i}(\mathrm{CS})}=6 ; \mathrm{pH}_{\mathrm{i}(\mathrm{CO})}=5.8 ; \mathrm{t}_{\mathrm{eq}}=24 \mathrm{~h} ; \mathrm{V} / \mathrm{m}=100\right.$ mL.g ${ }^{-1} ; C_{0}=20$ mg.L $\mathrm{L}^{-1}$; temp. $=25^{\circ} \mathrm{C}$ ).

\subsection{Sorption kinetics}

The sorption rate of $\mathrm{Cs}(\mathrm{I})$ and $\mathrm{Co}(\mathrm{II})$ onto the soil samples was illustrated using pseudo-first-order and pseudo- second-order models.

\subsubsection{Pseudo-first-order kinetic model}

Pseudo-first-order model was proposed in sorption of liquid to solid system that depends on the solid concentration. It was given by the following equation[40]:

$$
\log \left(q_{e}-q_{t}\right)=\log q_{e}-\frac{K_{f}}{2.303} t
$$

where: $\mathrm{q}_{\mathrm{e}}, \mathrm{q}_{\mathrm{t}}$ are the adsorbed amount of $\mathrm{Cs}(\mathrm{I})$ or $\mathrm{Co}(\mathrm{II})$ onto soil sample (mg.g $\left.{ }^{-1}\right)$ at equilibrium and at time $t$ and $k_{f}$ is the rate constant of pseudo-first-order $\left(\mathrm{min}^{-1}\right)$. The relation of $\log \left(\mathrm{q}_{\mathrm{e}}-\mathrm{q}_{\mathrm{t}}\right)$ and time for $\mathrm{Cs}(\mathrm{I})$ and $\mathrm{Co}$ (II) sorption onto studied soil samples are given in figures (7). The model constants were determined from the slope and intercept of the straight lines of the corresponding plots and their values along with the correlation coefficients $\left(\mathrm{R}^{2}\right)$ are illustrated in Table (2). This data illustrate that the adsorbed amounts $\left(\mathrm{q}_{\mathrm{e}}\right)$ of $\mathrm{Cs}(\mathrm{I})$ on DNS/C and DNS/Q soil samples, after reaching equilibrium, were found to be 0.28 and $0.43 \mathrm{mg} . \mathrm{g}^{-1}$, respectively while the experimental values were 0.45 and $0.94 \mathrm{mg} . \mathrm{g}^{-1}$. The sorbed amounts $\left(\mathrm{q}_{\mathrm{e}}\right)$ of $\mathrm{Co}(\mathrm{II})$ on DNS/C and DNS/Q samples were found to be 0.91 and $1.00 \mathrm{mg} \cdot \mathrm{g}^{-1}$, respectively while the experimental values were 1.58 and $1.79 \mathrm{mg} . \mathrm{g}^{-1}$. The data indicate that qe values estimated using pseudo-first-order kinetic model weren't consistent with the experimental qe values for both $\mathrm{Cs}(\mathrm{I})$ and $\mathrm{Co}(\mathrm{II})$. This confirms that the kinetics of Cs(I) and Co(II) sorption using the soil samples didn't follow pseudo-first-order reaction. In order to find a more reliable description of the sorption kinetics, pseudo-second-order kinetic equation was employed.
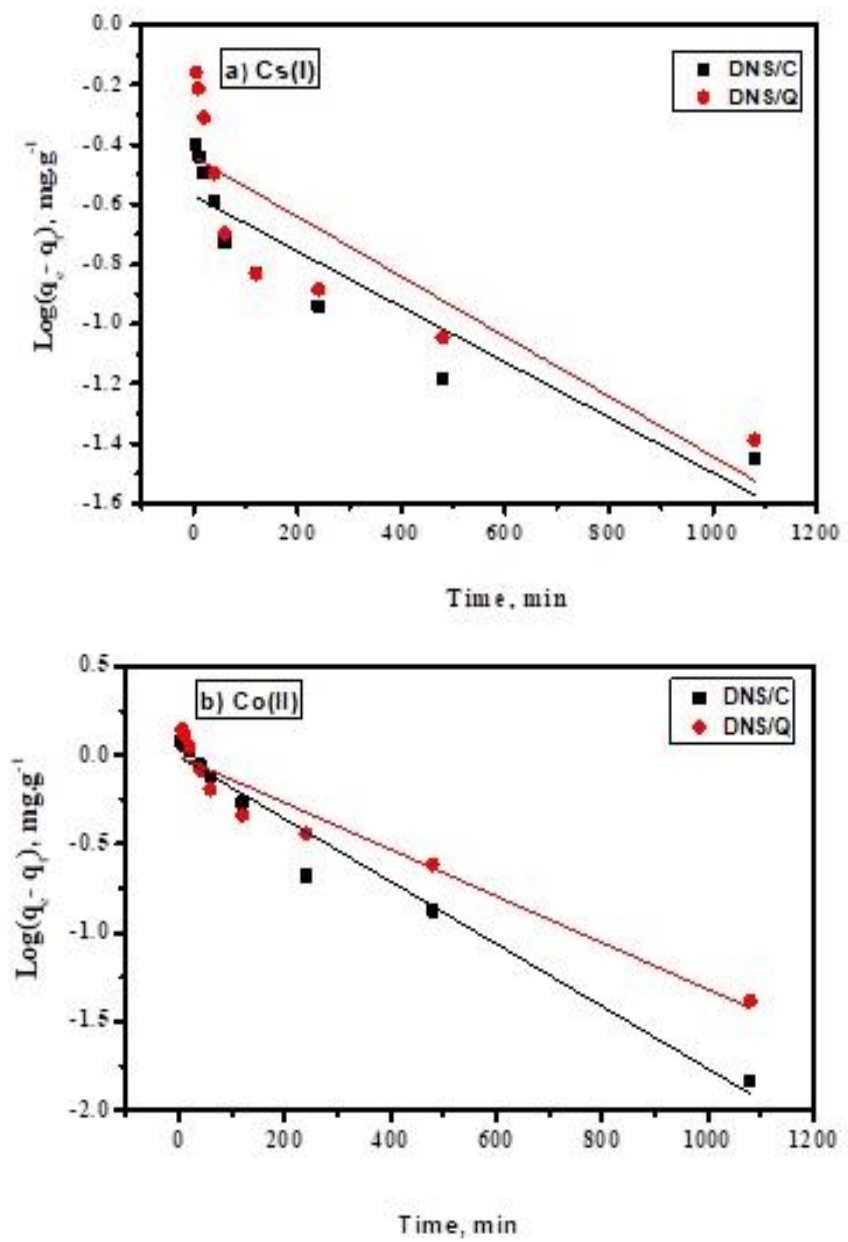

Fig. (7): Plots of pseudo-first-order for sorption of: a) $\mathrm{Cs}(\mathrm{I})$ and b) $\mathrm{Co}$ (II) ions onto the studied soil samples

Arab J. Nucl. Sci. Appl., Vol. 53, 4, (2020) 
Table (2): Pseudo-first-order constants for sorption of $\mathrm{Cs}(\mathrm{I})$ and $\mathrm{Co}(\mathrm{II})$ ions onto the studied soil samples

\begin{tabular}{llll}
\hline \multirow{2}{*}{ Cations } & \multirow{2}{*}{ Model constants } & \multicolumn{2}{l}{ Soil samples } \\
\cline { 3 - 4 } $\operatorname{Cs}(\mathrm{I})$ & $\mathrm{k}_{\mathrm{f}}\left(\mathrm{min}^{-1}\right)$ & 0.00216 & 0.002418 \\
& $\mathrm{q}_{\mathrm{e}}\left(\mathrm{mg}_{\mathrm{g}} \mathrm{g}^{-1}\right)$ & 0.27948 & 0.42702 \\
& $\mathrm{R}^{2}$ & 0.86064 & 0.84775 \\
& $\mathrm{~S} . \mathrm{D}$ & $-9.38 \mathrm{E}-04$ & $-1.05 \mathrm{E}-03$ \\
\hline \multirow{3}{*}{$\mathrm{Co}(\mathrm{II})$} & $\mathrm{k}_{\mathrm{f}}\left(\mathrm{min}^{-1}\right)$ & 0.004076 & 0.002902 \\
& $\mathrm{q}_{\mathrm{e}}\left(\mathrm{mg}_{\mathrm{g}} \mathrm{g}^{-1}\right)$ & 0.90832 & 0.999848 \\
& $\mathrm{R}^{2}$ & 0.9922 & 0.94834 \\
& $\mathrm{~S} . \mathrm{D}$ & $1.46 \mathrm{E}-04$ & $3.85 \mathrm{E}-04$ \\
\hline
\end{tabular}

\subsubsection{Pseudo-second-order kinetic model}

Pseudo-second-order model was used to describe the chemisorption kinetic of sorbate ions onto sorbent surface. The mathematical linear form of this model is given below [41]:

$$
\frac{\mathrm{t}}{\mathrm{q}_{\mathrm{t}}}=\frac{1}{\mathrm{k}_{\mathrm{s}} \mathrm{q}_{\mathrm{e}}^{2}}+\frac{1}{\mathrm{q}_{\mathrm{e}}} \mathrm{t}
$$

where: $\mathrm{k}_{\mathrm{s}}$ is the pseudo-second-order rate constant (g.mg$\left.{ }^{1} \min ^{-1}\right)$, the product $\left(\mathrm{k}_{\mathrm{s}} \mathrm{q}_{\mathrm{e}}^{2}\right)$ is the initial sorption rate represented as $h$. The relation between $t / q_{t}$ and $t$ for the sorption of $\mathrm{Cs}(\mathrm{I})$ or $\mathrm{Co}(\mathrm{II})$ ions onto the studied soil samples is represented in figure (8). The constant of pseudo-second-order model were estimated from the slope and intercept of the straight lines of the corresponding plots. The values of these constants and the correlation coefficients (R2) are given in Table (3). The data illustrate that the adsorbed amounts $\left(\mathrm{q}_{\mathrm{e}}\right)$ of $\mathrm{Cs}(\mathrm{I})$ on DNS/C and DNS/Q after reaching equilibrium were found to be 0.43 and $0.91 \mathrm{mg} \cdot \mathrm{g}^{-1}$ while the experimental values were 0.45 and $0.94 \mathrm{mg} \cdot \mathrm{g}^{-1}$. The adsorbed amounts $\left(\mathrm{q}_{\mathrm{e}}\right.$ ) of $\mathrm{Co}(\mathrm{II})$ on DNS/C and DNS/Q soil samples were found to be 1.62 and $1.81 \mathrm{mg} . \mathrm{g}^{-1}$, respectively while the experimental values were 1.58 and $1.79 \mathrm{mg} \cdot \mathrm{g}^{-1}$. The results illustrate that adsorbed amounts values determined from pseudo-second-order model were consistent with the experimental $\mathrm{q}_{\mathrm{e}}$ values for sorption of both $\mathrm{Cs}(\mathrm{I})$ and $\mathrm{Co}$ (II) ions and the correlation coefficient $\left(\mathrm{R}^{2}\right)$ is extremely high and closer to unity $\left(\mathrm{R}^{2}>0.998\right)$. This illustrated that sorption of $\mathrm{Cs}(\mathrm{I})$ and $\mathrm{Co}$ (II) onto the surface of applied soil samples could be represented by the kinetic of pseudo-second-order kinetics. Hence, rate-determining step in the sorption process is a chemisorption process dependent on the number of active sites on soil surface and the initial concentration of metal ions [42].
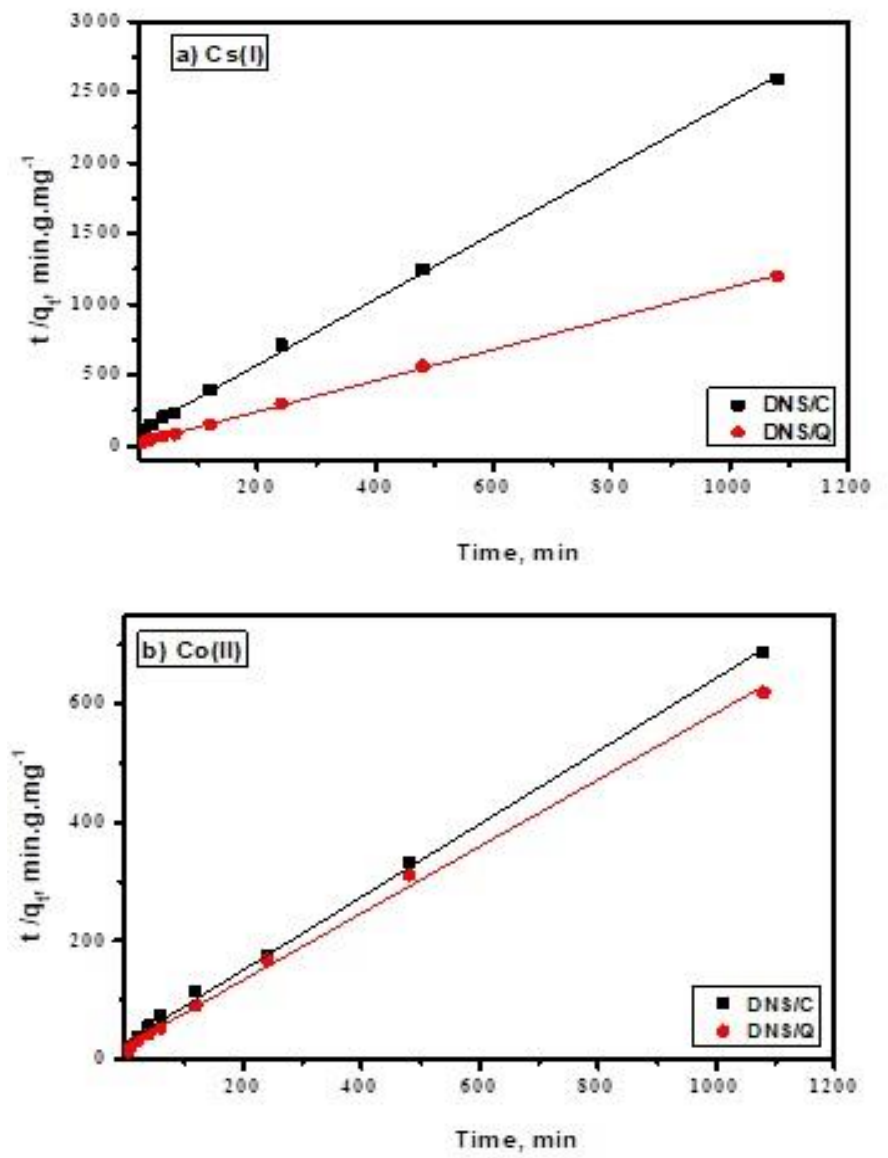

Fig. (8): Pseudo-second-order plots for sorption of: a) $\mathrm{Cs}(\mathrm{I})$ and b) $\mathrm{Co}(\mathrm{II})$ ions onto the studied soil samples

Table (3): Pseudo-second-order constants for sorption of $\mathrm{Cs}(\mathrm{I})$ and $\mathrm{Co}(\mathrm{II})$ ions onto the studied soil samples

\begin{tabular}{llll}
\hline \multirow{2}{*}{ Cations } & \multirow{2}{*}{ Model constants } & \multicolumn{2}{l}{ Soil samples } \\
\cline { 3 - 4 } Cs(I) & & DNS/C & DNS/Q \\
\hline \multirow{2}{*}{$\mathrm{k}_{\mathrm{s}}\left(\mathrm{g} \cdot \mathrm{mg}^{-1} \cdot \mathrm{min}^{-1}\right)$} & 0.050231 & 0.057879 \\
& $\mathrm{q}_{\mathrm{e}}\left(\mathrm{mg} \cdot \mathrm{g}^{-1}\right)$ & 0.430674 & 0.911195 \\
& $\mathrm{~h}\left(\mathrm{mg} \cdot \mathrm{g}^{-1} \cdot \mathrm{min}^{-1}\right)$ & 0.009318 & 0.048055 \\
& $\mathrm{R}^{2}$ & 0.99899 & 0.99952 \\
& $\mathrm{~S} . \mathrm{D}$ & $2.61 \mathrm{E}-02$ & $8.47 \mathrm{E}-03$ \\
\hline \multirow{3}{*}{$\mathrm{Co}(\mathrm{II})$} & $\mathrm{k}_{\mathrm{s}}\left(\mathrm{g} \cdot \mathrm{mg}^{-1} \cdot \mathrm{min}^{-1}\right)$ & 0.013756 & 0.013557 \\
& $\mathrm{q}_{\mathrm{e}}\left(\mathrm{mg}_{\mathrm{g}} \mathrm{g}^{-1}\right)$ & 1.628638 & 1.812908 \\
& $\mathrm{~h}\left(\mathrm{mg} \cdot \mathrm{g}^{-1} \cdot \mathrm{min}^{-1}\right)$ & 0.036487 & 0.044556 \\
& $\mathrm{R}^{2}$ & 0.99897 & 0.99945 \\
& $\mathrm{~S} . \mathrm{D}$ & $6.58 \mathrm{E}-03$ & $7.66 \mathrm{E}-03$ \\
\hline
\end{tabular}




\subsection{Sorption thermodynamics}

To investigate the effect of temperature on sorption of ${ }^{134} \mathrm{Cs}$ and ${ }^{60} \mathrm{Co}$ radionuclides onto the employed soil samples, the sorption experiments were conducted at different temperatures have the values 30, 35, 40 and 45 ${ }^{\circ} \mathrm{C}$ and the data obtained are given in figures (9). The plots show that the increase in temperature had a negative effect on sorption of cesium radionuclide where the sorption slightly decreased with increasing temperature figure (9a). This result was similar to that reported by Tertre and $\mathrm{Wu}$ [43]. This data indicated that sorption of cesium radionuclides onto the clay surface was favored at lower temperatures. On other hand, the sorption of cobalt was increased with rising temperature from $30^{\circ} \mathrm{C}$ to $45^{\circ} \mathrm{C}$, suggesting that sorption of cobalt onto soil samples are promoted at a higher temperature
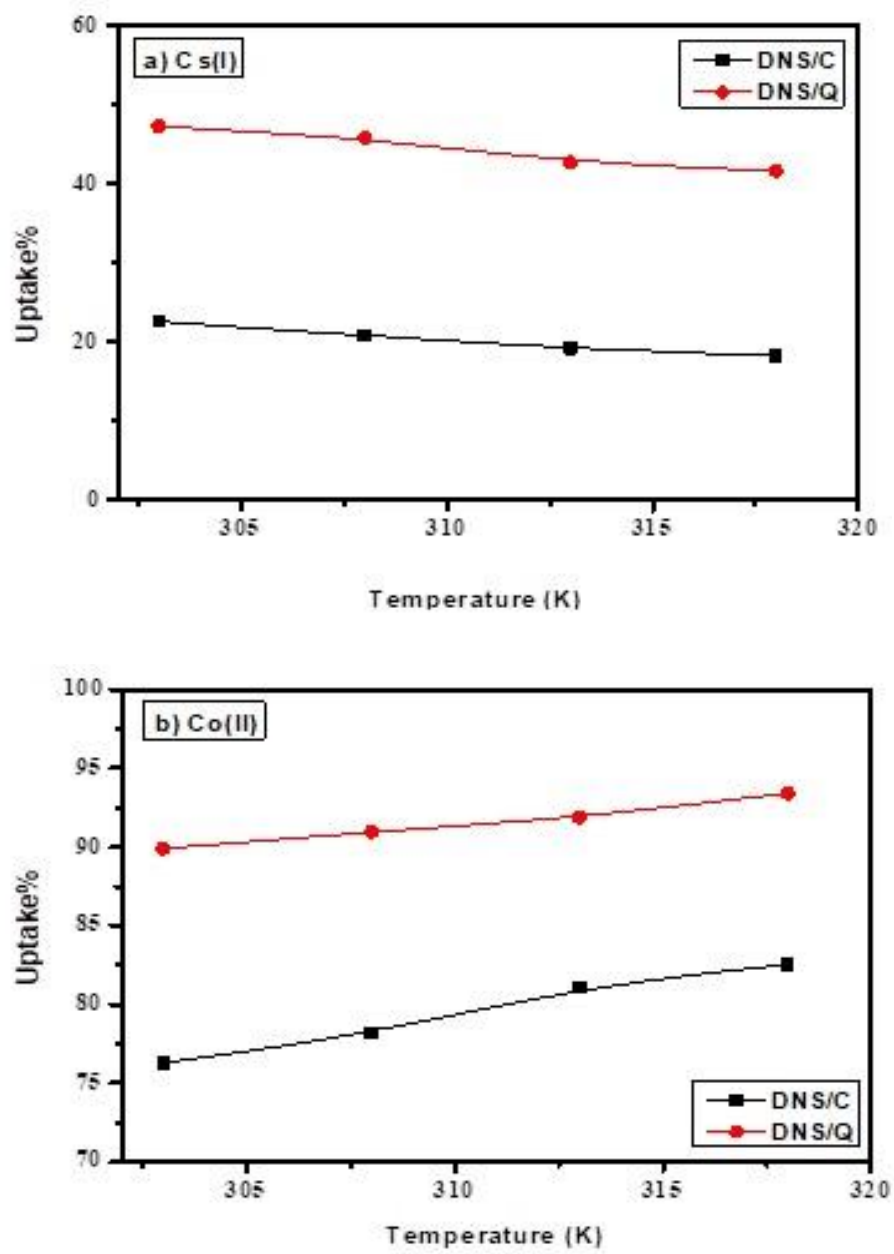

Fig. (9): Effect of temperature on uptake of: a) $\mathrm{Cs}(\mathrm{I})$ and b) $\operatorname{Co}($ II) ions onto the studied soil samples $\left(\mathrm{C}_{\mathrm{o}}=20 \mathrm{mg} . \mathrm{L}^{-1} ; \mathrm{pH}_{\mathrm{i}(\mathrm{Cs})}=6 ; \mathrm{pH}_{\mathrm{i}(\mathrm{Co})}\right.$ $=5.8 ; \mathrm{V} / \mathrm{m}=100 \mathrm{~mL} . \mathrm{g}^{-1} ; \mathrm{t}_{\mathrm{eq}}=24 \mathrm{~h}$; temp. = $\left.25^{\circ} \mathrm{C}\right)$
The revealed sorption data were used to estimate the thermodynamic parameters. The entropy change $\left(\Delta S^{\circ}\right)$ and enthalpy change $\left(\Delta \mathrm{H}^{\circ}\right)$ were determined from Van't Hoff equation [44]:

$$
\ln \mathrm{K}_{\mathrm{d}}=\frac{\Delta \mathrm{S}^{\mathrm{o}}}{\mathrm{R}}-\frac{\Delta \mathrm{H}^{\mathrm{o}}}{\mathrm{RT}}
$$

where: $\Delta \mathrm{S}^{\mathrm{o}}$ is the entropy change $\left(\mathrm{kJ} \cdot \mathrm{mol}^{-1} \cdot \mathrm{K}^{-1}\right), \Delta \mathrm{H}^{\mathrm{o}}$ is

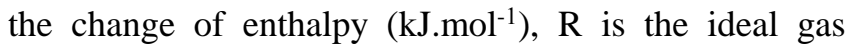
constant $\left(8.315 \times 10^{-3} \mathrm{~kJ} \cdot \mathrm{mol}^{-1} \cdot \mathrm{K}^{-1}\right)$ and $\mathrm{T}$ is the absolute temperature $\left({ }^{\circ} \mathrm{K}\right)$. The distribution coefficient $\left(\mathrm{K}_{\mathrm{d}}\right)$ for sorption of $\mathrm{Cs}(\mathrm{I})$ and $\mathrm{Co}(\mathrm{II})$ was determined using the equation:

$$
\mathrm{K}_{\mathrm{d}}=\frac{\mathrm{C}_{\mathrm{o}}-\mathrm{C}_{\mathrm{e}}}{\mathrm{C}_{\mathrm{e}}} \times \frac{\mathrm{v}}{\mathrm{m}}
$$

where: $K_{d}$ is the distribution coefficient (mL. $\left.\mathrm{g}^{-1}\right), \mathrm{C}_{\mathrm{o}}$ and $\mathrm{C}_{\mathrm{e}}$ are the initial and equilibrium concentrations of $\mathrm{Cs}(\mathrm{I})$ and $\mathrm{Co}(\mathrm{II})$ ions in solution $\left(\mathrm{mg} . \mathrm{L}^{-1}\right)$ respectively, $\mathrm{V}$ is the volume of solution $(\mathrm{mL})$ and $\mathrm{m}$ is the sorbent mass $(\mathrm{g})$. The relation of $\ln \mathrm{K}_{\mathrm{d}}$ versus $1 / \mathrm{T}$ for sorption of $\mathrm{Cs}(\mathrm{I})$ and $\mathrm{Co}$ (II) onto the soil samples is shown in figure (10). $\Delta \mathrm{H}^{\mathrm{o}}$ and $\Delta \mathrm{S}^{\mathrm{o}}$ values were calculated from the slope and the intercept of the straight lines of the corresponding plots and the values are listed in Tables (4). The free energy change $\left(\Delta \mathrm{G}^{\mathrm{o}}\right)$, is determined using the following equation:

$$
\Delta \mathrm{G}^{\mathrm{o}}=-\mathrm{RT} \ln \mathrm{K}_{\mathrm{d}}
$$

where: $\Delta \mathrm{G}^{\mathrm{o}}$ is the change of Gibbs free energy in $\left(\mathrm{kJ}^{\mathrm{mol}}{ }^{-1}\right)$. From Eq. (6), Eq. (8) can be written in the form:

$$
\Delta \mathrm{G}^{\mathrm{o}}=\Delta \mathrm{H}^{\mathrm{o}}-\mathrm{T} \Delta \mathrm{S}^{\mathrm{o}}
$$

Sorption of cesium radionuclide onto the studied clays gives negative $\Delta H^{\circ}$ values, which indicate the exothermic nature of this sorption process at the studied experimental conditions. The positive values of $\Delta \mathrm{H}^{\circ}$ for cobalt radionuclide indicate that the sorption process of this radionuclide onto the studied soils is endothermic process. The negative values of $\Delta \mathrm{S}^{\circ}$ recorded for Cs (I) ions onto the studied soils indicate less randomness at the soil-solution interface during sorption processes. The positive values of $\Delta \mathrm{S}^{\mathrm{o}}$ recorded for sorption $\mathrm{Co}$ (II) ions onto studied soils indicate the increased randomness at the soil-solution interface during the sorption processes. 
For $\Delta \mathrm{G}^{\mathrm{o}}$, the positive values of $\Delta \mathrm{G}^{\mathrm{o}}$ for cesium radionuclide with increasing temperature shows that its sorption onto studied soils is more thermodynamically feasible at lower temperatures and non- spontaneous. On the contrary, its negative values obtained under our experimental conditions for $\mathrm{Co}$ (II) ions indicate that the present sorption processes of $\mathrm{Co}$ (II) ions are thermodynamically feasible and spontaneous in nature. The increase in values of $-\Delta \mathrm{G}^{0}$ with increasing temperature from $30{ }^{\circ} \mathrm{C}$ to $45{ }^{\circ} \mathrm{C}$ demonstrates that sorption processes of cobalt radionuclide onto soil samples used in the present work are more feasible at higher temperatures.
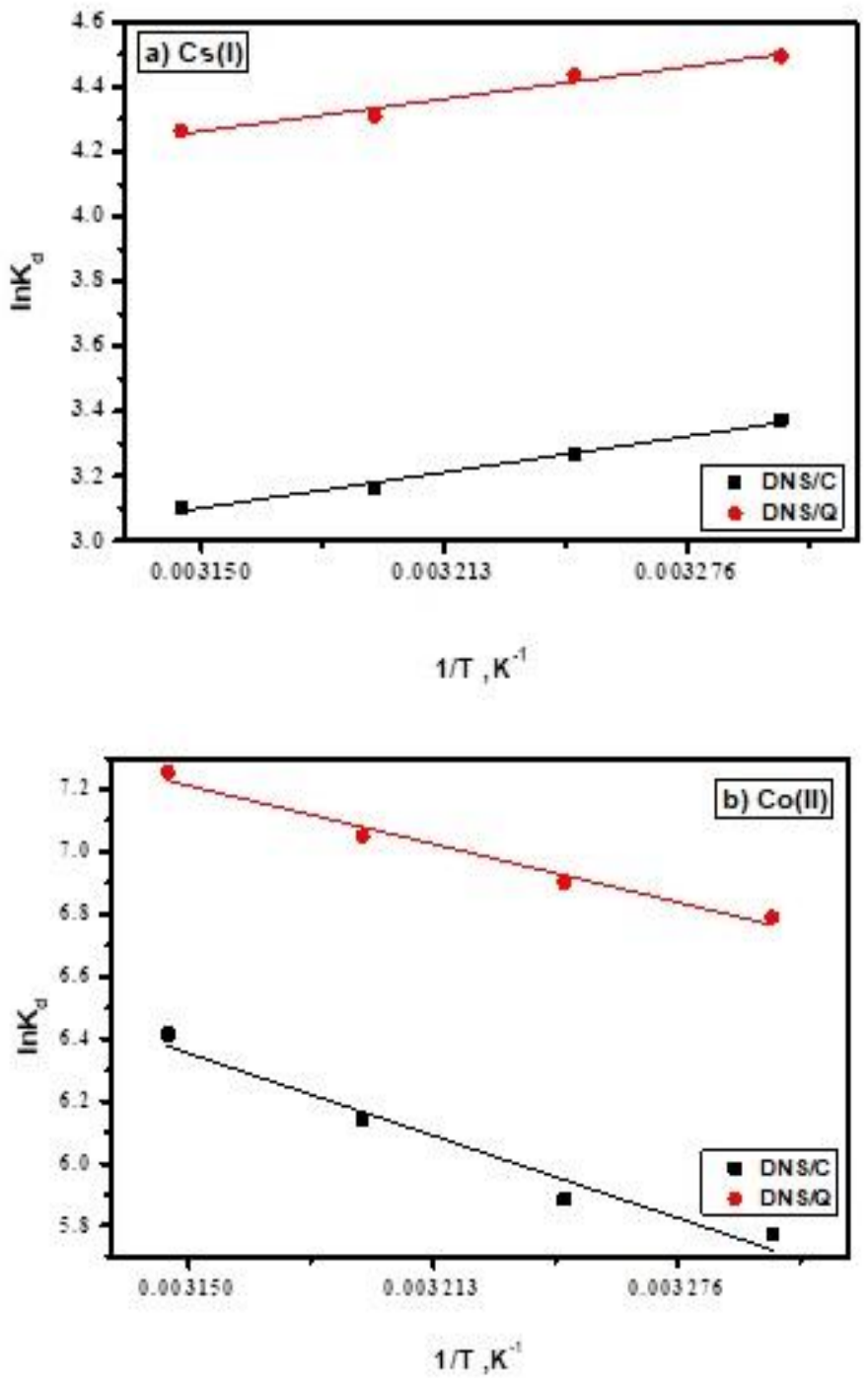

Fig. (10): Plots of $\ln K_{d}$ versus 1/T for sorption of: a) $\mathrm{Cs}(\mathrm{I})$ and b) $\mathrm{Co}(\mathrm{II})$ ions onto the studied soil samples.
Table (4): The values of thermodynamic parameters for sorption process of $\mathrm{Cs}(\mathrm{I})$ and $\mathrm{Co}$ (II) the studied soil samples

\begin{tabular}{|c|c|c|c|c|c|c|c|}
\hline \multirow{3}{*}{ Soil Sample } & \multirow{3}{*}{$\begin{array}{l}\text { Temp. } \\
\text { (K) }\end{array}$} & \multicolumn{6}{|c|}{ Element } \\
\hline & & \multicolumn{3}{|l|}{$\mathrm{Cs}^{+}$} & \multicolumn{3}{|l|}{$\mathrm{CO}^{2+}$} \\
\hline & & $\Delta G^{0}$ & $-\Delta \mathrm{H}^{0}$ & $-\Delta S^{0}$ & $-\Delta \mathrm{G}^{0}$ & $\Delta \mathrm{H}^{\circ}$ & $\Delta S^{0}$ \\
\hline \multirow{4}{*}{$\mathrm{DNS} / \mathrm{C}$} & 303 & 8.924 & \multirow{4}{*}{14.542} & \multirow{4}{*}{0.0774} & 0.329 & \multirow{4}{*}{22.064} & \multirow{4}{*}{0.07390} \\
\hline & 308 & 9.311 & & & 0.699 & & \\
\hline & 313 & 9.699 & & & 1.068 & & \\
\hline & 318 & 10.09 & & & 1.438 & & \\
\hline \multirow{4}{*}{ DNS/Q } & 303 & 6.065 & \multirow{4}{*}{13.096} & \multirow{4}{*}{0.0632} & 0.069 & \multirow{4}{*}{23.842} & \multirow{4}{*}{0.08025} \\
\hline & 308 & 6.382 & & & 0.567 & & \\
\hline & 313 & 6.698 & & & 1.065 & & \\
\hline & 318 & 7.014 & & & 1.563 & & \\
\hline
\end{tabular}

\section{CONCLUSION}

In the current study, sorption of $\mathrm{Cs}(\mathrm{I})$ and $\mathrm{Co}(\mathrm{II})$ ions onto DNS/C and DNS/Q soil samples collected from El-Dabaa site, Egypt, was investigated. DNS/Q have high affinity for sorption of $\mathrm{Cs}$ (I) and $\mathrm{Co}$ (II) ions under optimal conditions, where DNS/C have lower affinity for sorption for both metal ions as specific surface area are 10.532 and $17.970 \mathrm{~m}^{2} \cdot \mathrm{g}^{-1}$, d-spacing results from XRD are 3.02 and $3.32 \mathrm{~nm}$ for $\mathrm{DNS} / \mathrm{C}$ and $\mathrm{DNS} / \mathrm{Q}$ respectively and XRF analysis illustrate that percentages of Alumina $\left(\mathrm{Al}_{2} \mathrm{O}_{3}\right)$ for DNS/C and DNS/Q are 0.88 and $8.26 \%$ form the total weight that have great effect on uptake percent discussed in competing ion effect. Kinetic studies revealed that sorption of El-Dabaa soil soils for $\mathrm{Cs}(\mathrm{I})$ and $\mathrm{Co}(\mathrm{II})$ radionuclides were compatible with pseudo-second-order model estimated that the sorption process followed it and has a chemisorption behavior.

\section{ACKNOWLEDGEMENTS}

Authors are grateful to Egyptian Atomic Energy Authority for providing the different facilities to carry out this study.

\section{REFERENCES}

[1] Ding, C., Cheng, W., Sun, Y. and Wang, X. (2015) Novel Fungus- $\mathrm{Fe}_{3} \mathrm{O}_{4}$ Bio-Nanocomposites as High Performance Adsorbents for the Removal of Radionuclides, J. Hazard. Mater., 295,127-137.

[2] Schröder, J., Rossignol, N. and Oudheusden, M. (2016) Safety in Long Term Radioactive Waste Management: Insight and Oversight, Saf. Sci., 85, 265-285. 
[3] Abdelhady, A. (2013) Radiological Performance of Hot Water Layer System in Open Pool Type Reactor. Alex. Eng. J., 52, 159-162.

[4] Abou Elmaaty, T. (2015) Experimental Investigation of the Hot Water Layer Effect on Upward Flow Open Pool Reactor Operability, Arab J. Nucl. Sci. Appl., 48(1), 73-80.

[5] IAEA. Technical Data Serious No. In 356. Vienna: International Atomic Energy Agency, (1993) 15.

[6] Zhang, L., Wei, J., Zhao, X., Li, F., Jiang, F., Zhang, M. and Cheng, X. (2016) Competitive Adsorption of Strontium and Cobalt onto Tin Antimonite, Chem. Eng. J., 270,279-285.

[7] Guajardo, A.E., Liamas, J.C., Maqueira, L., Andrade, C.S., Alves, K.B. and Melo, C.P. (2015) Efficient Removal of $\mathrm{Cr}(\mathrm{VI})$ and $\mathrm{Cu}(\mathrm{II})$ Ions from Aqueous Media by Use of Polypyrrole/Maghemite and Polyaniline/Maghemite Magnetic Nanocomposites, Chem. Eng. J., 281, 826-836.

[8] Barakat, M. A. and Kumar, R. (2015) Synthesis and Characterization of Porous Magnetic Silica Composite for the Removal of Heavy Metals from Aqueous Solution, J. Indus. Eng. Chem., 23, 93-99.

[9] Rahman, I. M., Begum, Z.A. and Hasegawa, H. (2013) Selective Separation of Elements from Complex Solution Matrix with Molecular Recognition Plus Macrocycles Attached to a SolidPhase: A review, Microchem. J., 110, 485-493.

[10] Wang, Z., Ma, Y., Hao, X., Huang, W., Guan, G. and Abudula, A. (2014) Enhancement of Heavy Metals Removal Efficiency From Liquid Wastes by Using Potential-Triggered Proton Self-Exchange Effects, Electrochim. Acta 130, 40-45.

[11] Ali, I., Asim, M. and Khan, T.A. (2013) Arsenate Removal from Water by Electrocoagulation on Zinc-Zinc and Copper-Copper electrodes, Int. J. Environ. Sci. Technol., 10, 377-384.

[12] Ali, I. (2014) Water Treatment by Adsorption Columns: Evaluation at Ground Level, Sep. Purif. Rev., 43, 175-205.

[13] Wu, Y., Zhang, J., Liu, J., Chen, L., Deng, Z., Han, M., Yu, A., Zhang, H. and Wei, X. (2012) $\mathrm{Fe}_{3} \mathrm{O}_{4}$ and $\mathrm{ZrO}_{2}$ Nanoparticles Magnetic Solid Phase Extraction Coupled with Flame Atomic Absorption Spectrometry for Chromium(III) Speciation in Environmental and Biological Samples, Appl. Surf. Sci., 258, 6772-6776.
[14] Dolatyari, L., Yaftian, M. and Rostamnia, S. (2016) Removal of Uranium(VI) Ions from Aqueous Solutions Using Schiff Base Functionalized SBA15 Mesoporous Silica Materials, J. Environ. Manage., 169, 8-17.

[15] Tan, L., Liu, O., Jing, X., Liu, J., Song, D., Hu, S., Liu, L. and Wang, J. (2015) Removal of Uranium(VI) Ions from Aqueous Solution by Magnetic Cobalt Ferrite/Multiwalled Carbon Nanotubes Composites, Chem. Eng. J., 273, 307315.

[16] Hafid, N., Belaatar, M., Ben-Aazza, S., Hadfi, A., Ezahri, M. and Driouiche, A. (2015) Characterization of Scale Formed in Drinking Water and Hot Water Pipes in the Taliouine Downtown-Morocco, Am. J. Anal. Ch. 6 (8), 677686.

[17] Wang, Y., Moo, Y. X., Chen, C., Gunawan, P. and $\mathrm{Xu}$, R. (2010) Fast Precipitation of Uniform $\mathrm{CaCO}_{3}$ Nanospheres and Their Transformation to Hollow Hydroxyapatite Nano Spheres, J. Colloid Interface Sci., 352(2), 393-400.

[18] Linga Raju, C., Narasimhulu, K. V., Gopal, N. O., Rao, J. L. and Reddy, B. C. V. (2002) Electron Paramagnetic Resonance, Optical and Infrared Spectral Studies on the Marine Mussel Arca Burnesi Shells, J. Mol. Str., 608 (2-3), 201-211.

[19] Cheng, B., Cai, W. and Yu, J. (2010) DNAMediated Morphosynthesis of Calcium Carbonate Particles, J. Colloid Interface Sci., 352 (1), 43-49.

[20] Ndukwe, N. A. and Jenmi, F. O. (2008) Effects of Vehicular Exhaust Fumes on Urban Air Pollution in Lagos Metropolis, Poll. Res., 27 (3),539-543.

[21] Shan, D., Wang, S., Xue, H. and Cosnier, S. (2007) Direct Electrochemistry and Electrocatalysis of Hemoglobin Entrapped in Composite Matrix Based on Chitosan and $\mathrm{CaCO}_{3}$ Nanoparticles, Electrochem. Commun., 9, 529-534.

[22] Nguyen, T. T., Janik, L.J. and Raupach, M. ((1991) Diffuse Reflectance Infrared Fourier Transform (DRIFT) spectroscopy in Soil Studies, Aust. J. Soil Res., 29, 49-67.

[23] Apte, S. K., Naik, S.D., Sonawane, R. S. and Kalew, B. B. (2007) Synthesis of Nanosizenecked Structure a- and $\mathrm{g}-\mathrm{Fe}_{2} \mathrm{O}_{3}$ and its Photocatalytic Activity, J. Am. Ceram. Soc., 90, 412-414. 
[24] Murray, C. A. and Greytak, T. J. (1979) Intrinsic Surface Phonons in Amorphous Silica, Phys. Rev., 20, 3368 .

[25] Falini, G., Fermani, S., Gazzano, M. and Ripamonti, A. (1998) Structure and Morphology of synthetic Magnesium Calcite, J. Mater. Chem., 8, 10611065.

[26] Hazen, R. M., Finger, L. W., Hemley, R. J. and Mao, H. K. (1989) High-Pressure Crystal Chemistry and Amorphization of Alpha-Quartz Locality: Synthetic Sample: $\mathrm{P}=1$ bar, Sol. St. Comm., 72, 507-511.

[27] Trucano, P. and Chen, R. (1975) Structure of Graphite by Neutron Diffraction Locality: Soil Crystals, Nat., 258, 136-137.

[28] Wang, K. and Reeber, R. R. (1996) Thermal Expansion of Alkali Halides at High Pressure: $\mathrm{NaCl}$ as an Example Sample: $\mathrm{T}=300 \mathrm{~K}$, Molar Volume $=26.98 \mathrm{cc} / \mathrm{mol}$, Phys. Chem. of Min., 23, 354-360.

[29] Gualtieri, A. and Venturelli, P. (1999) In Situ Study of the Goethite-Hematite Phase Transformation by Real Timesynchrotron Powder Diffraction Sample at T $=779$ C, Am. Min., 84, 895-904.

[30] Levien, L., Prewitt, C. T. and Weidner, D. J. (1980) Structure and Elastic Properties of Guartz at Pressure $\mathrm{P}=1 \mathrm{~atm}$, Am. Min., 65, 920-930.

[31] Antao, S. M., Mulder, W. H., Hassan, I., Crichton, W. A. and Parise, J. B. (2004) Cation Disorder in Dolomite, $\mathrm{CaMg}\left(\mathrm{CO}_{3}\right)_{2}$ and its Influence on the Aragonite - Magnesite - Dolomite Reaction Boundary Sample: $\mathrm{P}=3 \mathrm{GPa}, \mathrm{T}=1320 \mathrm{~K}, \mathrm{Am}$. Min., 89, 1142-1147.

[32] Ott, H. (1926) Die Strukturen von $\mathrm{MnO}, \mathrm{MnS}, \mathrm{AgF}$, $\mathrm{NiS}, \mathrm{SnI}_{4}, \mathrm{SrCl}_{2}, \mathrm{BaF}_{2}$, Praezisionsmessungen einiger Alkalihalogenide. Zeitschrift fuer Kristallographie, Kristallgeometrie, Kristallphysik, Kristallchemie, 63, 222-230.

[33] Brigatti, M. F., Frigieri, P. and Poppi, L. (1998) Crystal Chemistry of Mg-, Fe-Bearing Muscovites-2M1Sample from Peraluminous Granites at Northern Victoria Land, Antarctica, Am. Min., 83, 775-785.

[34] Attallah, M. F., Borai, E.H. and Shady, S.A. (2014) Kinetic Investigation for Sorption of Europium and Samarium from Aqueous Solution Using
Resorcinol-Formaldehyde Polymeric Resin, $J$. Radioanal. Nucl. Chem., 299, 1927-1933.

[35] Xia, M., Zheng, X., Du, M., Wang, Y., Ding, A. and Dou, J. (2018) The Adsorption of $\mathrm{Cs}^{+}$from Wastewater Using Lithium-Modified Montmorillonite Caged in Calcium Alginate Beads, Chem. Sph., 203, 271-280.

[36] Khandaker, S., Toyohara, Y., Kamida, S. and Kuba, T. (2018) Effective Removal of Cesium from Wastewater Solutions Using an Innovative Low-Cost Adsorbent Developed from Sewage Sludge Molten Slag, J. Env. Manag., 222, 304315.

[37] Olatunji, M., Khandaker, M., Mahmud, E., Amin, Y., Ademola, J. and Olorode, D. (2018) Remediation of ${ }^{137} \mathrm{Cs}$ Radionuclide in Nuclear Waste Effluents by Polymer Composite: Adsorption Kinetics, Isotherms and Gamma Irradiation Studies, J. Radioanal. Nucl. Chem., 316 (3), 933-945.

[38] Yavari, R. and Huang, Y. D. (2010) Uptake Behavior of Titanium Molybdophosphate for Cesium and Strontium, J. Radioanal. Nucl. Chem.,286, 223-229.

[39] Tewari, P. H., Campelle, A. B. and Lee, W. (1972) Adsorption Studies of Cobalt(II) on Manganese Dioxide from Aqueous Solutions. J. Chem., 50, 1642.

[40] Lagergren, S. (1898) Zur Theorie der Sogenannten Adsorption Gelöster Stoffe, K. Sven. Vetenskapsakad. Handl Band 24, 1-39.

[41] Ho, Y.S. and McKay G. (1999) Pseudo-SecondOrder Model for Sorption Processes, Process Biochem., 34, 451-465.

[42] Ding, D., Zhao, Y., Yang, S.J., Shi, W.S., Zhang, Z.Y., Lei, Z.F. and Yang, Y.N. (2013) Adsorption of Cesium from Aqueous Solution Using Agricultural Residue-Walnut Shell: Equilibrium, Kinetic and Thermodynamic Modeling Studies, Wat. Res., 47 (7), 2563-2571.

[43] Tertre, E., Berger, G. and Castet, S. (2005) Experimental Sorption of $\mathrm{Ni}^{2+}, \mathrm{Cs}^{+}$and $\mathrm{Ln}^{3+}$ onto a Montmorillonite up to $150{ }^{\circ} \mathrm{C}, \mathrm{J}$. Geochim. Cosmochim. Acta, 69, 4937-4948.

[44] Choppin, G.R. and Morgenstern, A. (2000) Thermodynamics of Solvent Extraction, Solvent Extr. Ion Exch., 18(6), 1029-1049. 